\title{
Factors Influencing Undergraduate Software Engineering Course Choice Among Students
}

\author{
André Barros de Sales \\ University of Brasília - UnB \\ Gama, DF, Brazil \\ andrebdes@unb.br
}

\author{
Paula Meyer Soares \\ University of Brasília - UnB \\ Gama, Brazil \\ paulameyer@unb.br
}

\author{
Tatiane da Silva Evangelista \\ University of Brasília - UnB \\ Gama, Brazil \\ tatilista@unb.br
}

\begin{abstract}
This article examines the factors influencing the students that attend the Gama Faculty at the University of Brasilia when choosing the Software Engineering Undergraduate Course. Exploratory research and quantitative approach. The data were collected through a questionnaire applied to 61 incoming undergraduate students who wished to attend the referred undergraduate course in November 2019. The results revealed that the choice of the Software Engineering course is related to the students' affinity with the profession, but the financial compensation and the employability also influence on the course choice. The results also revealed that the choice of the University of Brasilia institution is mainly related to reputation, quality of teaching, student recommendation and employability, due to the institution's name.
\end{abstract}

\section{KEYWORDS}

Software Engineering, Motivation, Career choice.

\section{INTRODUCTION}

Digital technology is increasingly present in people's everyday lives. According to the Brazilian Institute of Geography and Statistics - IBGE [1], in 2016 and 2017, the main means of Internet access were cell phones, followed by the connection by microcomputers, television and tablets. In this report, IBGE reveals that in the period 2016-2017, Internet access via cell phone grew from $94.6 \%$ to $97 \%$, and in the same period, this access rose from $85 \%$ to $88 \%$ and from $25 \%$ to $31.1 \%$ in the age groups 18 to 24 years and over 60 years, respectively.

Sales and Boscarioli [2] consider digital social technologies as those that allow social interaction and collaborative practices, allowing students to choose control of their own learning, mediated by a range of resources, including audio, video, group management and data storage and sharing. The authors also emphasize that many of these technologies were not designed for the teaching and learning process, but to provide good usability in any field of application.

In higher education institutions worldwide, there is a multitude of small-scale and integration experiences from a variety of social software resources into educational practices.

Due to technological and scientific advances in the last decades, the need for qualified professionals for the labor market is growing $[3,4]$. One of the undergraduate courses in the area of Computing Science is the Software Engineering course.

Implemented in the second half of 2008 [5], the Bachelor's Degree in Software Engineering at the University of Brasilia (UnB) was the first in Brazil, followed by the course at the Federal University of Goiás (UFG) in 2009, and those at the Federal University of Ceará (UFC), the Federal University of Pampa (UNIPAMPA) and the Federal University of Rio Grande do Norte (UFRN) in 2010.

The University of Brasilia offers 5 undergraduate courses in the Computer Science area (Bachelor in Computer Science, Computer Engineering, Degree in Computing, Mechatronic Engineering and Software Engineering).

The UnB undergraduate Software Engineering course is held at the Gama Faculty, established through the Support Program for the Restructuring and Expansion of Federal Universities [6], instituted by Decree No. 6.096/2007 [7].

Gama Faculty offers 280 openings per semester (single entry) for the 5 undergraduate courses in Aerospace Engineering, Automotive Engineering, Energy Engineering, Electronics Engineering and Software Engineering, with 56 openings for each course.

According to Darcy Ribeiro's project in creating the University of Brasilia, undergraduate students have the opportunity to choose a profession once they are more mature and well informed about the different fields to which they could apply [8]. Following this principle, upon entering the Gama Faculty, undergraduate students initiate the "Basic Cycle" of Engineering, and may decide to choose one of the five engineering courses after the first semester. At this point, there are no restrictions on when and how many students should choose a certain course.

According to the University of Brasilia Statistical Yearbook of 2019 , from 2014 to 2019, the number of undergraduate students regularly enrolled in undergraduate programs in the area of Computer Science at the University of Brasilia increased as follows: Bachelor of Computer Science, from 381 to 408; Computer Engineering, from 329 to 420; Computer Degree, from 300 to 346; Mechatronic Engineering, from 391 to 418 and Software Engineering, from 297 to 575 [9]. It is important to stress that the increase in the Software Engineering course represented more than $95 \%$.

Software Engineering is one of the courses offered at Gama Faculty (FGA) along with Aerospace Engineering, Automotive Engineering, Electronic Engineering and Energy Engineering. These are 5 relatively new courses, still offered by few institutions in Brazil. Gama Faculty is located in the city of Gama, about $35 \mathrm{~km}$ from the center of Brasilia.

The Software Engineering course has the highest number of students among those offered at FGA and among Computing courses offered at the central campus of the University of Brasilia [9] [10]. FGA was created in 2008 through a Brazilian public policy directed towards expanding access to higher education in the country.

In view of the presented numbers, the following question emerges: Why are students choosing the undergraduate course in Software 
Engineering? Coming from such context and to answer such question, this study aims to investigate the factors influencing undergraduate Software Engineering course choice among students at the University of Brasilia.

This article is organized as follows: Section 2 presents the methodology; Section 3 discusses the results, and Section 4 presents concluding remarks.

\section{METHODOLOGY}

Regarding the research purposes, the present study is exploratory "with the objective of providing an approximate overview of a certain fact" [11]. The research approach is quantitative [12]. The analyzed social group comprised undergraduate students from Gama Faculty at the University of Brasilia, aspirants to the undergraduate Software Engineering course.

This study is the first stage of a research project that will investigate, over a period of 5 years, the reasons for choosing the Software Engineering course, as well as what are the expectations of the newcomers for their professional training, whether they were met during the course and which Information and Communication Technologies (ICT) are used in the collaborative teaching and learning process.

Data were collected by applying a paper questionnaire to undergraduate students. The questionnaire consisted of 15 questions, three open-ended and 12 multiple-choice questions. Some of the multiple-choice questions made use of a Likert scale.

The questionnaire's objective was to survey and understand aspects associated with the choice of the Software Engineering course and the choice of the University of Brasilia.

The questionnaire was organized in three blocks: (i) the first block, on the profile of the respondents (age, gender, attending period, form of entry, engineering of interest); (ii) the second block includes questions on the factors related to the choice of the undergraduate Software Engineering course; and (iii) the third block addresses the factors related to the choice of the University of Brasilia.

The questions related to the second and third blocks were based on the research carried in the undergraduate Management and Accounting courses by Araújo et al. [13] and Miranda et al. [14].

Of the 280 newcomers to the first term of Gama Faculty's engineering courses, 148 undergraduate students agreed to participate voluntarily in the survey after reading and signing a consent form, representing $52.9 \%$ of the total, creating a confidence range of over $90 \%$ with an error margin of $5 \%$.

Considering the 148 students who agreed to participate, the focus of this survey is the group of 61 students who expressed the desire to pursue a degree in Software Engineering through the questionnaire. Analyses and data from this survey refer to this group of undergraduate students.

The questionnaire was applied in November 2019, during the beginning of classes in some subjects of the first period.

Regarding demographic variables, the profile of respondents was outlined as follows: 52 men (85.2\%), 8 women (13.1\%) and 1 (1.6\%) non-respondent; age group between 17 and 26 years, mostly between 18 and 19 years $(72.1 \%) .60(98.4 \%)$ respondents were attending the first term of the college and $1(1.6 \%)$ did not respond.
Regarding the participants' family income, 24 (39.3\%) earn more than 10 minimum wages, $16(26.2 \%)$ are in the range of 5 to 10 minimum wages, $9(14.8 \%)$ are in the range of 2 to 5 minimum wages, $4(6.6 \%)$ are in the range of up to two minimum wages and $8(13.1 \%)$ did not respond.

Data obtained from participants answers were tabulated and inferences were extracted based on its analysis. All percentage values of the research are rounded to one decimal place.

\section{DISCUSSION OF RESULTS}

This section is divided into three subsections. The first presents the results obtained in the questionnaire responses on the profile, the second gives details on the factors related to the choice of the undergraduate course in Software Engineering and the third on factors related to the choice of the University of Brasilia.

\subsection{Profile and Devices Used in Learning Activities}

Data collected revealed the following forms of university entrance: $52.5 \%$ from the Serial Evaluation Program (PAS); $41 \%$ from the Traditional Entrance Examination; 1.6\% from the Entrance Examination for Remaining Places; $1.6 \%$ from higher education graduates; and $1.6 \%$ from course transference. The remaining collected data on their profile covered the devices used in their study activities and the resources employed to seek more knowledge in the discipline.

Regarding the devices used in study activities by undergraduate students, laptops are the most used, representing $77 \%$, followed by Smartphones, $72.1 \%$, Desktop Computers, 52.5\%, Tablets, $11.5 \%$, and finally Netbooks presenting $3.3 \%$ of totality.

Table 1 shows the percentage of resources used to seek additional knowledge in the disciplines. Video lessons and YouTube were the most used resources to seek more knowledge in the disciplines by students, with $82 \%$ and $80.3 \%$ respectively.

Table 1: Used resources for additional knowledge in the disciplines

\begin{tabular}{lc}
\hline Resources & $\begin{array}{c}\text { Percentage } \\
\text { of Students }\end{array}$ \\
\hline Video lesson & $82 \%$ \\
YouTube & $80.3 \%$ \\
E-book & $59 \%$ \\
Digital media materials provided by instructors & $54.1 \%$ \\
Educational websites & $52.5 \%$ \\
Books & $47.5 \%$ \\
Scientific papers & $44.3 \%$ \\
Wikipedia & $23 \%$ \\
Wiki platform of students' papers from previous & $16.4 \%$ \\
semesters & \\
Wiki platform of students' papers from the cur- & $8.2 \%$ \\
rent semester & \\
\hline
\end{tabular}

The wiki of student work from previous semesters and the wiki of work from other students in the same class were the least used 
resources to search for more knowledge in the subjects, with $16.4 \%$ and $8.2 \%$, respectively.

To uncover the difficulties expected in the course of Software Engineering (Table 2), the questionnaire presented a list of options to which the student could assign a score from 1 to 5 ( 1 being the minimum score and 5 the maximum). "Getting an internship in the area" and the "programming subjects" were the two major difficulties expected during the course, with a mean of 3.2 in both, but with standard deviations of 1 and 1.2 respectively. "English language" is the expected difficulty with a lower mean, 2.4 and a standard deviation of 1.3 .

Table 2: Expected difficulties in conducting the course

\begin{tabular}{|c|c|c|c|c|c|c|c|c|}
\hline \multirow[b]{2}{*}{ Motive: } & \multicolumn{6}{|c|}{ Absolute Frequency } & \multirow[b]{2}{*}{ Mean } & \multirow[b]{2}{*}{$\begin{array}{l}\text { Standard } \\
\text { Deviation }\end{array}$} \\
\hline & 0 & 1 & 2 & 3 & 4 & 5 & & \\
\hline $\begin{array}{l}\text { Getting an internship in the } \\
\text { area }\end{array}$ & 1 & 2 & 10 & 23 & 19 & 6 & 3.2 & 1 \\
\hline Programming subjects & 0 & 6 & 13 & 14 & 17 & 11 & 3.2 & 1.2 \\
\hline Mathematics & 0 & 10 & 11 & 11 & 20 & 9 & 3.1 & 1.3 \\
\hline Study and work conciliation & 0 & 18 & 1 & 14 & 15 & 13 & 3.1 & 1.5 \\
\hline English language & 1 & 23 & 5 & 19 & 9 & 4 & 2.4 & 1.3 \\
\hline
\end{tabular}

About the intention to work later as a Software Engineer, the questionnaire presented a list of options to which the student could assign a score from 1 to 5 . Results are presented in Table 3.

Being "employed in a large company in a big city" was the most motivating, with a mean score of 3.9 and standard deviation of 1.1, followed by the desire to be an " entrepreneur in the area", with a mean score of 3.4 and standard deviation of 1.3, and "to own their company", with a mean score of 3.2 and standard deviation of 1.5.

The options that attracted less interest from respondents were "Academic (professor/researcher)", with a mean of 2.4 and a standard deviation of 1.6, "public-sector employee in other areas" with a mean of 2.3 and a standard deviation of 1.5 , and finally "consultant," with a mean of 2.2 and a standard deviation of 1.3 .

Table 3: Professional intentions

\begin{tabular}{|c|c|c|c|c|c|c|c|c|}
\hline \multirow[b]{2}{*}{ Professional Intentions: } & \multicolumn{6}{|c|}{ Absolute Frequency } & \multirow[b]{2}{*}{ Mean } & \multirow[b]{2}{*}{$\begin{array}{l}\text { Standard } \\
\text { Deviation }\end{array}$} \\
\hline & 0 & 1 & 2 & 3 & 4 & 5 & & \\
\hline $\begin{array}{l}\text { To work in a large company } \\
\text { in a large center }\end{array}$ & 3 & 5 & 0 & 4 & 23 & 26 & 3.9 & 1.1 \\
\hline Entrepreneur in the area & 3 & 11 & 3.3 & 14 & 18 & 17 & 3.4 & 1.3 \\
\hline Own their company & 4 & 11 & 3 & 10 & 16 & 17 & 3.2 & 1.5 \\
\hline $\begin{array}{l}\text { Employed in medium and } \\
\text { small companies }\end{array}$ & 4 & 12 & 7 & 19 & 14 & 5 & 2.7 & 1.3 \\
\hline $\begin{array}{l}\text { Public-sector employee in the } \\
\text { area }\end{array}$ & 4 & 18 & 8 & 9 & 15 & 7 & 2.6 & 1.5 \\
\hline $\begin{array}{l}\text { Academic (Instructor / Re- } \\
\text { searcher) }\end{array}$ & 5 & 24 & 1 & 12 & 10 & 9 & 2.4 & 1.6 \\
\hline $\begin{array}{l}\text { Public-sector employee in } \\
\text { other areas }\end{array}$ & 4 & 24 & 3 & 11 & 15 & 4 & 2.3 & 1.5 \\
\hline Consultant & 4 & 21 & 8 & 15 & 12 & 1 & 2.2 & 1.3 \\
\hline
\end{tabular}

Regarding the use of communication tools with faculty colleagues for general notices and meeting scheduling, students noted the ones used. For each selected tool they could assign a score from
1 to 5 ( 1 being the minimum score and 5 the maximum score) for the level of usage, knowledge and difficulty.

Table 4 shows that WhatsApp is the most widely used application, with 59 respondents $(96.7 \%)$.

It generated a mean score of 4.7 with a standard deviation of 0.6 for the level of usage, and a mean score of 4.4 with a standard deviation of 0.8 for the level of knowledge on the application. The difficulty of usage created a mean score of 1.2 with a standard deviation of 0.6 .

The second most utilized tool for general notices and meeting scheduling was Telegram, with 20 students (32.8\%), mean 3.2 and standard deviation of 1.1 for the level of use; mean 2.9 with standard deviation 1.2 for the level of knowledge of the tool; the mean of the level of difficulty in using the application was 2.2 with standard deviation 1.3.

Next, answers are presented on the tools used for non-presential meetings to carry out college activities with colleagues, in which WhatsApp prevails, with 52 students $(85.2 \%)$. The second most used tool was Discord with 47 students (77\%), followed by Skype with $9(14.8 \%)$, Google hangouts with $4(6.6 \%)$. The least used tool was TeamSpeak, with 1 student (1.65\%).

Regarding the preferred tools for collaborative file storage where the group members could store and retrieve the project(s) files. Google Drive is the tool used by most students, 52 (85.2\%). Dropbox is used by 7 students (11.5\%), followed by WhatsApp with $2(3.3 \%)$, Microsoft One Drive with 1 (1.6\%) and other with 6 (9.8\%).

\subsection{Factors influencing undergraduate Software Engineering course choice Among Students}

Concerning data collection on the factors that influenced the choice for the undergraduate Software Engineering course, students could assign a score from 1 to 5 (being 1 the minimum score and 5 the maximum) for each question.

Table 5 shows that the two most pointed factors were: "taste for the work line" with mean 4.3 and standard deviation of 1 ; and "affinity with professional activities" with mean 4.1 and standard deviation of 1.1. Followed by "salary" with an average of 3.9 and standard deviation of 1; and "higher chances of employment" with an average of 3.9 and standard deviation of 1.2.

The main factors for influencing undergraduate Software Engineering course choice among students are directly or indirectly linked to the job market. This same perception was observed in the study by Araujo et al. [13] with freshman students in the undergraduate course in Administration and by Miranda et al. [14] with students entering the undergraduate course in Accounting.

It is observed that the choice for the Software Engineering course is mainly related to professional taste and affinity, but financial compensation and employability are also highly valued aspects.

This result can be considered a positive aspect, since personal identification with the course and the promising market are important reasons for satisfaction with the profession [15].

In addition, if the course is considered as a goal chosen autonomously, there will be greater engagement, greater investment 
Table 4: Tools utilized for general notices and meeting scheduling

\begin{tabular}{|c|c|c|c|c|c|c|c|c|c|}
\hline \multirow[b]{2}{*}{ Tool: } & \multirow[b]{2}{*}{ Number of respondents } & \multirow[b]{2}{*}{ Interaction } & \multicolumn{5}{|c|}{ Relative Frequency } & \multirow[b]{2}{*}{ Mean } & \multirow[b]{2}{*}{ Standard Deviation } \\
\hline & & & 1 & 2 & 3 & 4 & 5 & & \\
\hline \multirow{3}{*}{ WhatsApp } & \multirow{3}{*}{$59(96.7 \%)$} & Usage & $0 \%$ & $1,7 \%$ & $3.4 \%$ & $16.9 \%$ & $78 \%$ & 4.7 & 0.6 \\
\hline & & Knowledge (expertise) & $0 \%$ & $1.7 \%$ & $15.3 \%$ & $22 \%$ & $61 \%$ & 4.4 & 0.8 \\
\hline & & Difficulty & 91.5 & $5.1 \%$ & $1.7 \%$ & $0 \%$ & $1.7 \%$ & 1.2 & 0.6 \\
\hline \multirow{3}{*}{ Telegram } & \multirow{3}{*}{$20(32.8 \%)$} & Usage & $0 \%$ & $35 \%$ & $30 \%$ & $20 \%$ & $15 \%$ & 3.2 & 1.1 \\
\hline & & Knowledge (expertise) & $15 \%$ & $25 \%$ & $35 \%$ & $10 \%$ & $15 \%$ & 2.9 & 1.2 \\
\hline & & Difficulty & $45 \%$ & $20 \%$ & $15 \%$ & $15 \%$ & $5 \%$ & 2.2 & 1.3 \\
\hline \multirow{3}{*}{ SMS } & \multirow{3}{*}{$3(4.9 \%)$} & Usage & $66,7 \%$ & $0 \%$ & $33.3 \%$ & $0 \%$ & $0 \%$ & 1.7 & 0.9 \\
\hline & & Knowledge (expertise) & $0 \%$ & $0 \%$ & $0 \%$ & $0 \%$ & $100 \%$ & 5 & 0 \\
\hline & & Difficulty & $66.7 \%$ & $0 \%$ & $33.3 \%$ & $0 \%$ & $0 \%$ & 1.7 & 0.9 \\
\hline
\end{tabular}

of efforts and energy for its achievement, as people are more effective when pursuing goals that involve personal interests or express their personal values [16].

Table 5: Level of factors influencing undergraduate Software Engineering course choice among students

\begin{tabular}{|c|c|c|c|c|c|c|c|c|}
\hline \multirow[b]{2}{*}{ Factors of Influence: } & \multicolumn{6}{|c|}{ Absolute Frequency } & \multirow[b]{2}{*}{ Mean } & \multirow[b]{2}{*}{$\begin{array}{l}\text { Standard } \\
\text { Deviation }\end{array}$} \\
\hline & 0 & 1 & 2 & 3 & 4 & 5 & & \\
\hline Taste for the work line & 0 & 3 & 1 & 4 & 21 & 32 & 4.3 & 1 \\
\hline $\begin{array}{l}\text { Affinity with professional activi- } \\
\text { ties }\end{array}$ & 0 & 4 & 2 & 5 & 25 & 25 & 4.1 & 1.1 \\
\hline Salary & 0 & 1 & 2 & 19 & 17 & 22 & 3,9 & 1 \\
\hline Higher chances of employment & 0 & 3 & 6 & 8 & 20 & 24 & 3.9 & 1.2 \\
\hline High school subject's affinity & 0 & 4 & 6 & 17 & 13 & 21 & 3.7 & 1.2 \\
\hline Professional status & 0 & 5 & 5 & 21 & 16 & 14 & 3,5 & 1.2 \\
\hline Current job growth & 1 & 15 & 5 & 14 & 15 & 5 & 3 & 1.4 \\
\hline $\begin{array}{l}\text { Ideal course for setting up a busi- } \\
\text { ness }\end{array}$ & 0 & 13 & 8 & 17 & 16 & 7 & 2.9 & 1.3 \\
\hline Friend indication & 0 & 17 & 10 & 14 & 16 & 4 & 2,7 & 1.3 \\
\hline Career guidance & 1 & 19 & 5 & 13 & 19 & 4 & 2.7 & 1.4 \\
\hline Family indication & 0 & 26 & 4 & 15 & 11 & 5 & 2.4 & 1.4 \\
\hline Easy entrance exams & 1 & 38 & 8 & 5 & 7 & 2 & 2.3 & 4.1 \\
\hline Model high school teacher & 0 & 32 & 7 & 11 & 8 & 3 & 2.1 & 1.3 \\
\hline High school teacher indication & 0 & 33 & 6 & 12 & 7 & 3 & 2 & 1.3 \\
\hline Parents' business or profession & 0 & 40 & 1 & 11 & 6 & 3 & 1.9 & 1.3 \\
\hline Technical course continuation & 0 & 41 & 4 & 3 & 3 & 1 & 1.7 & 1.1 \\
\hline Boss recommendation & 0 & 44 & 4 & 11 & 2 & 0 & 1.5 & 0.9 \\
\hline
\end{tabular}

About higher chances of employment in Software Engineering, the 2020 version of the Future of Jobs Survey [17] reveals the leading positions in growing demand are roles related to Software Engineering such as Data Analysts and Scientists, AI and Machine Learning Specialists, Robotics Engineers, Software and Application developers as well as Digital Transformation Specialists.

The three factors with the lowest scores: "parents' business / profession" with a mean of 1.9 and a standard deviation of 1.3 ; " technical course continuation" with a mean of 1.7 and a standard deviation of 1.1; and " boss recommendation" with mean a of 1.5 and a standard deviation of 0.9 .

\subsection{Factors influencing University of Brasilia choice Among Students}

In search of factors influencing the choice for University of Brasilia, students could assign a score from 1 to 5 ( 1 being the minimum score and 5 the maximum) for each question.
Table 6 shows that the two factors with highest scores were: "known as good university" with mean 4.7 and standard deviation 0.4; "teaching quality" with mean 4.7 and standard deviation 0.5 . This was followed by " students' recommendation" with a mean of 3.9 and standard deviation 1; "ease of employment" with a mean of 3.8 and a standard deviation of 1.1.

Table 6: Level of factors influencing University of Brasilia choice Among Students

\begin{tabular}{|c|c|c|c|c|c|c|c|c|}
\hline \multirow[b]{2}{*}{ Factors of Influence: } & \multicolumn{6}{|c|}{ Absolute Frequency } & \multirow[b]{2}{*}{ Mean } & \multirow[b]{2}{*}{$\begin{array}{l}\text { Standard } \\
\text { Deviation }\end{array}$} \\
\hline & 0 & 1 & 2 & 3 & 4 & 5 & & \\
\hline Known as a good university & 1 & 0 & 0 & 0 & 13 & 47 & 4.7 & 0.4 \\
\hline Teaching quality & 1 & 0 & 0 & 2 & 11 & 47 & 4.7 & 0.5 \\
\hline Students' recommendation & 2 & 3 & 2 & 10 & 26 & 19 & 3.9 & 1 \\
\hline Ease of employment & 1 & 2 & 5 & 13 & 18 & 22 & 3.8 & 1.1 \\
\hline Qualified academic staff & 3 & 2 & 3 & 19 & 15 & 19 & 3.7 & 1.1 \\
\hline Curricula & 1 & 4 & 8 & 18 & 18 & 12 & 3.4 & 1.1 \\
\hline Service quality & 2 & 6 & 4 & 20 & 13 & 16 & 3.4 & 1.2 \\
\hline Family recommendation & 1 & 11 & 2 & 15 & 15 & 17 & 3.4 & 1.4 \\
\hline Infrastructure & 1 & 4 & 9 & 23 & 14 & 10 & 3.2 & 1.1 \\
\hline Security (location and access) & 1 & 4 & 17 & 20 & 13 & 6 & 3 & 1.1 \\
\hline College friends & 1 & 17 & 6 & 17 & 13 & 7 & 2.7 & 1.4 \\
\hline Ease of access & 1 & 17 & 10 & 16 & 7 & 10 & 2.7 & 1.4 \\
\hline Employee recommendation & 1 & 18 & 9 & 22 & 5 & 6 & 2.5 & 1.3 \\
\hline Easy entrance exam & 1 & 26 & 16 & 13 & 2 & 3 & 2 & 1.1 \\
\hline
\end{tabular}

The choice for the University of Brasilia is mainly related to reputation, quality of teaching and student recommendation, but employability due to the name of the institution is also a relevant factor.

Factors that presented the lowest scores: "college friends" with mean 2.7 and standard deviation 1.4; "ease of access" with mean 2.7 and standard deviation 1.4; "employees recommendation" with mean 2.5 and standard deviation 1.3; and "easy entrance exam" with mean 2 and standard deviation 1.1.

\section{CONCLUDING REMARKS}

This article focused on identifying and analyzing factors that determine the choice for the Software Engineering undergraduate course, based on a sample of 61 new graduates at the Gama Faculty at the University of Brasilia. This is an exploratory and quantitative research, whose analyzed social group were candidates to the undergraduate course in Software Engineering at the Gama Faculty at the University of Brasilia. 
Despite the limitations of the research, it is concluded that in order to choose the Software Engineering course, students considered four factors of major relevance, in decreasing order of importance: taste for line of work, professional affinity, salary and higher chances of employment. The Software Engineering course choice is mainly related to taste and affinity with the profession, but financial compensation and employability are also highly valued when choosing the course.

Regarding the selection of the University of Brasilia, the research revealed that the five most relevant factors, in descending order of importance, were: known as good university, quality of teaching, student recommendation, ease of employment and qualified academic staff. The University of Brasilia's choice is mainly related to reputation, quality of teaching and student recommendation, but employability due to the institution's name also indicates relevance.

On the profile of this group of undergraduate students, this article presented the social digital tools that are used to support cooperative work in a collaborative teaching-learning process. These digital technologies are hereby considered as social due to the interaction promoted amongst students. Results revealed that the most used social digital technologies were WhatsApp for communication; WhatsApp and Discord for videoconferencing; and Google Drive for collaborative file storage.

Results of this research also revealed the most frequently used devices in study activities: Notebooks, followed by Smartphones and Desktop Computers.

The listed results can be used as indicators for the choice factors and contribute to uncover the profile of the Software Engineering candidates, as well as precipitate institutional actions aimed at: (i) the entrants' expectations, considering that the training received during graduation should considerably influence their expectations and future professional choices, thus improving the teachinglearning process; (ii) meeting the growing number of students on the course; and (iii) assisting the selection of ICTs in these students' teaching and learning activities.

Regarding the research limitations and new studies organization, it should be desirable to expand the answers analysis or complementing the used survey with open questions is stressed, as well as the possibility of employing another method through which detailed information on the motivation for choosing a higher education area can be collected.

Furthermore, in future studies, the obtained information within this geographical and temporal context can be compared with that of other regions or periods. In addition, it is intended to statistically analyze the results of this research. As a future work, the analysis of the factors of the choice of engineering courses of the Faculty of Gama at the University of Brasilia is in progress.

\section{REFERENCES}

[1] Instituto Brasileiro de Geografia e Estatística. Pesquisa nacional por amostra de domicílios: Acesso à internet e à televisão e posse de telefone móvel celular para uso pessoal: 2017, 2018. URL https://biblioteca.ibge.gov.br/index.php/bibliotecacatalogo?view $=$ detalhes\&id $=2101631$.

[2] André Barros de Sales and Clodis Boscarioli. Uso de Tecnologias Digitais Sociais no Processo Colaborativo de Ensino e Aprendizagem. RISTI - Revista Ibérica de Sistemas e Tecnologias de Informação, (37):82 - 98, 06 2020. ISSN 1646-9895. doi: 10.17013/risti.37.82âĂŞ98. URL http://dx.doi.org/10.17013/risti.37.82\T1 textendash 98 .
[3] André Barros de Sales, Mauricio Serrano, and Milene Serrano. Aprendizagem baseada em projetos na disciplina de interação humano-computador. RISTI Revista Ibérica de Sistemas e Tecnologias de Informação, (37):49 - 64, 06 2020. ISSN 1646-9895. doi: 10.17013/risti.37.49-64. URL http://www.scielo.mec.pt/scielo.php? script=sci_arttext\&pid=S1646-98952020000200005\&nrm=iso.

[4] André Barros de Sales and Mateus Sousa e Silva. Jogos sérios no processo de ensino e aprendizagem de interação humano-computador. In Anais do XXXI Simpósio Brasileiro de Informática na Educação, pages 552-561, Porto Alegre, RS, Brasil, 2020. SBC. doi: 10.5753/cbie.sbie.2020.552. URL https://sol.sbc.org.br/ index.php/sbie/article/view/12811.

[5] Rejane M. da Costa Figueiredo, André Barros de Sales, Luiz Carlos M. Ribeiro Jr., Luís Augusto F. Laranjeira, and Adson Rocha. Teaching software quality in an interdisciplinary course of engineering. In 2010 Seventh International Conference on the Quality of Information and Communications Technology, pages 144-149, Porto, Portugal, 2010. IEEE. doi: 10.1109/QUATIC.2010.28. URL https: //ieeexplore.ieee.org/document/5654795.

[6] Ministério da Educação. Reestruturação e expansão das universidades federais reuni: Diretrizes gerais, 2007. URL http://portal.mec.gov.br/sesu/arquivos/pdf/ diretrizesreuni.pdf.

[7] BRASIL. Institui o programa de apoio a planos de reestruturação e expansão das universidades federais - reuni, 2007. URL http://www.planalto.gov.br/ccivil_03/ ato2007-2010/2007/decreto/d6096.htm.

[8] Darcy Ribeiro. Universidade De Brasília: Projeto De Organização, Pronunciamento De Educadores E Cientistas. Editora Universidade de Brasília, Brasília, Brazil, 2011.

[9] Universidade de Brasília. Anuário estatístico da unb 2019 período: 2014 a 2018, 2019. URL http://www.dpo.unb.br/images/phocadownload/unbemnumeros/ anuarioestatistico/AnuarioEstatistico2019.pdf.

[10] André Barros de Sales and Marcelino Monteiro de Andrade. Impacto da alta evolução do número de discentes no curso de graduação em engenharia de software da universidade de brasília. Revista de Ensino de Engenharia, 39:441-449, 2020. ISSN 2236-0158. doi: 10.37702/REE2236-0158.v39p441-449.2020. URL http://revista.educacao.ws/revista/index.php/abenge/article/view/1795.

[11] Antonio Carlos Gil. Como elaborar projetos de pesquisa. Atlas, São Paulo,Brazil, 1st edition, 2018. ISBN 978-8597012613.

[12] Mark Kasunic. Designing an effective survey. Technical report, Carnegie-Mellon Univ Pittsburgh PA Software Engineering Inst, 2005.

[13] Sergio Paulo Muniz de Araujo, João Maurício Gama Boaventura, Renato Telles, João Paulo Lara de Siqueira, and André Ricardo Robic. Fatores de escolha da carreira de administração e da instituição de ensino. Administração: Ensino e Pesquisa, 11(2):163-190, 2010. ISSN 2358-0917. doi: 10.13058/raep.2010.v11n2.141. URL https://raep.emnuvens.com.br/raep/article/view/141.

[14] Claudio de Souza Miranda, Adriana Maria Procópio Araujo, and Raissa Alvares de Matos Miranda. Perfil e expectativas dos ingressantes do curso de ciências contábeis: Um estudo em instituições de ensino superior do interior paulista. Revista de Gestão, Finanças e Contabilidade, 5(1):04-40, 2015. ISSN 2238-5320. doi: 10.18028/rgfc.v5i1.725. URL https://www.revistas.uneb.br/index.php/financ/ article/view/725.

[15] Marúcia Patta Bardagi and Ângela Carina. Trajetória acadêmica e satisfação com a escolha profissional de universitários em meio de curso. Revista Brasileira de Orientação Profissional, 4:153 - 166, 12 2003. ISSN 16793390. URL http://pepsic.bvsalud.org/scielo.php?script=sci_arttext\&pid=S167933902003000100013\&nrm=iso.

[16] Kennon M. Sheldon and Andrew J. Elliot. Not all personal goals are personal: Comparing autonomous and controlled reasons for goals as predictors of effort and attainment. Personality and Social Psychology Bulletin, 24(5):546-557, 1998. doi: 10.1177/0146167298245010. URL https://doi.org/10.1177/0146167298245010.

[17] World Economic Forum. The future of jobs report 2020. Geneva, Switzerland, 2020. World Economic Forum. URL https://www.weforum.org/reports/the-future- ofjobs-report-2020. 